\title{
Influence of resolution in spatial and time for numerical modeling of levees
}

\author{
Maciej Dwornik, Anna Pięta
}

AGH University of Science and Technology, Faculty of Geology, Geophysics and Environmental Protection, Department of Geoinformatics and Applied Computer Science; al. Mickiewicza 30, 30-059 Krakow, Poland; e-mail:dwornik@geol.agh.edu.pl,apieta@geol.agh.edu.pl

(C) 2015 Authors. This is an open access publication, which can be used, distributed and reproduced in any medium according to the Creative Commons CC-BY 4.0 License requiring that the original work has been properly cited.

Stability of geotechnical constructions, such as levees, is one of the most important issues for urban areas. The precise prediction of levees destruction during the flood can not only save human lives and properties, but also protect the natural environment (Krzhizhanovskaya et al. 2011). During ISMOP project (Computer System for Monitoring River Embankments), an artificial levee will be built and monitored using dense grid of sensors, mainly thermal and pore pressure ones. Planned levee will be an enclosed region with the water inside embankments. This construction will be placed in Czernichów near Kraków (Poland), close to existing Vistula River embankment (ISMOP 2014).

The main aim of the project is to create a remote system, which can inform about possibility of losing levee stability. Water level changes and its influence on the stability of levee was preceded by $2 \mathrm{D}$ and $3 \mathrm{D}$ numerical modeling, conducted in Itasca Flac software (Itasca 2011) based on finite-difference method. The modeling of levee behavior at various water levels (simulation of the flood waves) allow to select appropriate scenarios for real experiments and indicate the optimal location of sensors. It is important, because only limited number of scenarios can be performed in real conditions.

The first step included several 2D numerical modelings performed to obtain relevant shape and size of grid cells and offset of boundary condition (Bukowska \& Krawiec 2014, Pięta \&
Dwornik 2014) for mechanical and fluid calculation. Numerical modeling for both thermal and dynamic analysis force using regular computational grid with smaller size of computational cells than the cell used for fluid modeling. Other specifications (adaptive shape or bigger than $0.1 \mathrm{~m}$ cell size) caused instability in calculation of thermal fields. It also determines the depth of computational model in order to preserve natural exchange temperature between air, soil and water. Another problem was time step of modeling. Too short time step cause in a huge number of data, increasing calculation time and could make some calculations unstable or incorrect. Too long time step can cause incorrect prediction of destruction model and inadequately simulate natural phenomena of dynamic processes. Results obtained for 2D mechanical modeling were confirmed with 3D modeling of full levee and geological background. The lack of other processes in 3D modeling was caused by very long time of modeling the fluid-soil interaction.

Results of two dimensional numerical modeling shows, that $2 \mathrm{D}$ modelling can be regarded as a powerful and sufficient tool to estimate the stability of levee. The optimal size of grid and time step can make this calculation more efficient.

This work is financed by the National Centre for Research and Development (NCBiR), Poland, project PBS1/B9/18/2013 (no. 180535). 


\section{REFERENCES}

Bukowska-Belniak B. \& Krawiec K., 2014. Influence of the shape and density of grid computing to the accuracy of the numerical simulation of the flood embankments model. $14^{\text {th }}$ GeoConference on Informatics, Geoinformatics and Remote Sensing, 643-649, DOI:10.5593/ sgem2014B21.

Itasca Consulting Group Inc., 2011. FLAC Fast Langrangian Analysis of Continua. User Manual. Minneapolis, Minnesota.
Krzhizhanovskaya V.V., Shirshov G., Melnikova N., Belleman R.G., Rusadi F., Broekhuijsen B., Gouldby B., Lhomme J., Balis B., Bubak M. et al., 2011. Flood early warning system: design, implementation and computational modules. Procedia Computer Science, 4, 106-115.

Pięta A. \& Dwornik M., 2014. Analysis of boundary conditions offset for the accuracy of the numerical modeling of the levees. $14^{\text {th }}$ GeoConference on Informatics, Geoinformatics and Remote Sensing, 457-464, DOI:10.5593/ sgem 2014B21.

Project ISMOP (www.ismop.edu.pl). 